\title{
A SYSTEM FOR THE MULTI-CHANNEL TRANSCUTANEOUS STIMULATION OF THE AURICULAR NERVE
}

\author{
SISTEM ZA VEČKANALNO TRANSKUTANO STIMULACIJO \\ UŠESNE VEJE ŽIVCA VAGUSA
}

\author{
Janez Rozman 1,2*, Andrej Bartolič ${ }^{3}$, Aicha Ibrahim Maiga², Samo Ribarič² \\ ${ }^{1}$ Center for Implantable Technology and Sensors, ITIS d. o. o. Ljubljana, Lepi pot 11, 1000 Ljubljana \\ ${ }^{2}$ Institute of Pathophysiology, Faculty of Medicine, University of Ljubljana, Zaloška 4, 1000 Ljubljana \\ ${ }^{3}$ Splošna bolnišnica Nova Gorica, Ulica padlih borcev 13A, 5290 Sempeter pri Gorici
}

Prejem rokopisa - received: 2018-10-30; sprejem za objavo - accepted for publication: 2019-03-27

doi:10.17222/mit.2018.233

\begin{abstract}
The purpose of the study was to model, design and test a four-channel system for the selective transcutaneous stimulation of an auricular branch of the vagus nerve. In the model, four stimulating sites at the cymba conchae (CC) were identified. Thereafter, a four-channel plug containing four globule-like platinum cathodes was developed to be inserted into the external ear, while the common anode was placed onto the neck. To assess the performance of the cathodes, an equivalent circuit model (ECM) of the interface at the cathode and the anode was constructed. Then, corresponding ensemble elements, namely, the capacitance $C_{\mathrm{a}}$, resistance $R_{\mathrm{a}}$, phase angle $\theta_{\mathrm{a}}$ and impedance $|Z|_{\mathrm{a}}$ of an interface between a particular cathode when located at the CC and the anode, were measured at $1 \mathrm{kHz}$ and at $2.5 \mathrm{kHz}$. Finally, a voltage response at a particular cathode with respect to the anode and biphasic current stimulating pulses was measured under stimulating conditions. The results show that optimum stimulating charge density at a particular cathode was $2.40 \mu \mathrm{C} / \mathrm{mm}^{2}$, while the anodic charge density was $0.773 \mathrm{nC} / \mathrm{mm}^{2}$. Furthermore, averaged elements of the ECM had larger values when measured at $1 \mathrm{kHz}$ than when measured at $2.5 \mathrm{kHz}$. It was observed that elements of an actual load, i.e., $C_{\mathrm{a}}, R_{\mathrm{a}},|Z|_{\mathrm{a}}$ and $\theta_{\mathrm{a}}$, varied with the variations of the pressure that was applied on the plug because the layers of the skin bent into a basin surrounding the different surface area of the globule. In conclusion, the cathodic charge density was sufficiently high to stimulate subcutaneous neural structures, while the anodic charge density was too low to cause any stimulating effect. Furthermore, the plug should be pushed into an external ear using a steady force of approximately $2.5 \mathrm{~N}$ as provided by the spring within the dummy headphones.

Keywords: transcutaneous nerve stimulation, vagus nerve, cymba conchae, auricular nerve, platinum electrodes, impedance

Namen študije je bil modelirati, izdelati in testirati štirikanalni sistem za selektivno površinsko stimulacijo ušesne veje živca vagusa. V modelu so bila na področju cymba conchae (CC) identificirana štiri stimulacijska mesta. Zatem je bil razvit štirikanalni vstavek za namestitev v zunanje uho, ki je vseboval štiri platinaste katode v obliki kroglice, skupna anoda pa je bila nameščena na vrat. Za pridobitev lastnosti katod je bil konstruiran model nadomestnega vezja (ECM) prehoda med katodo in anodo. Nato so bile izmerjene vrednosti pripadajočih skupnih elementov, in sicer kapacitivnosti $C_{\mathrm{a}}$, upornosti $R_{\mathrm{a}}$, faznega kota $\theta$ in impedance $|Z|_{\text {a }}$ prehoda med posamezno katodo, ko je nameščena na CC in anodo, tako pri frekvenci $1 \mathrm{kHz}$ kot pri frekvenci $2,5 \mathrm{kHz}$. Nazadnje je bil pri stimulacijskih pogojih z izmeničnimi tokovnimi stimulacijskimi impulzi izmerjen tudi odgovor na posamezni katodi glede na anodo. Rezultati so pokazali, da je optimalna gostota stimulacijskega naboja na posamezni katodi 2,4 $\mu \mathrm{C} / \mathrm{mm}^{2}$, medtem ko je gostota naboja na anodi $0,773 \mathrm{nC} / \mathrm{mm}^{2}$. Poleg tega so bile izmerjene povprečne vrednosti elementov ECM večje pri frekvenci $1 \mathrm{kHz}$ kakor pri frekvenci $2,5 \mathrm{kHz}$. Opazili smo, da so se vrednost elementov dejanskega bremena: $C_{\mathrm{a}}$, $R_{\mathrm{a}},|Z|_{\mathrm{a}}$ in $\theta_{\mathrm{a}}$ spreminjale tako kot se je spreminjal pritisk na vstavek, ker so se plasti kože ukrivljale v kotanjico, ki je obdajala različno veliko površino kroglice. Lahko sklepamo, da je gostota stimulacijskega naboja na posamezni katodi dovolj velika, da stimulira podkožne strukture, medtem ko je gostota naboja na anodi premajhna, da bi izzvala kakršenkoli stimulacijski učinek. Poleg tega je potrebno vstavek pritiskati v zunanje uho s konstantno silo približno 2,5 N, ki jo zagotavljajo prirejene slušalke.

Ključne besede: transkutana stimulacija živca, živec vagus, cymba conchae, ušesni živec, platinaste elektrode, impedanca
\end{abstract}

\section{INTRODUCTION}

Neuromodulation is among the fastest-growing areas of medicine, involving many diverse specialties and impacting large populations of patients with numerous disorders worldwide. Vagus nerve stimulation (VNS) builds on a long history of investigating the relationship of autonomic signals to internal organs and glands with cortical function. In this regard, over the last several decades, VNS has been the subject of considerable research with the goal of using it to treat nervous system and neuropsychiatric disorders, eating disorders, sleep-

*Corresponding author's e-mail:

janez.rozman@guest.arnes.si ing disorders, cardiac disorders, endocrine disorders, and pain. ${ }^{1-5}$

VNS refers to any technique that stimulates the vagus nerve, including manual or electrical stimulation. In this regard, transcutaneous vagus nerve stimulation (TES) is a diagnostic and therapeutic approach based on normalizing the body's dysfunction through the stimulation of definite points of the ear. ${ }^{6-9}$ These definite points differ from others in terms of the receptor availability and density, such as nociceptor Golgi-tendon receptors, Meissner corpuscles, Krause's end-bulbs and glomus-bodies located primarily in the skin or viscera that respond to damaging stimuli by sending signals via slowly conducting afferent $\mathrm{A} \delta$ and $\mathrm{C}$ fibres to the spinal cord and 
the brain. ${ }^{10-12}$ The sensory innervation of an external ear is supplied primarily by branches of the cranial nerves $\mathrm{V}$ and $\mathrm{X}$ and from the cervical plexus, as well as branches from the cranial nerves VII and IX. However, innervation of the auricle and ear canal with these nerves overlaps such that the precise distribution of these nerves is not constant.

Mechanisms underlying the effects of both invasive and non-invasive VNS have been described by E. Frangos et al., ${ }^{13}$ who demonstrated functional magnetic resonance imaging (fMRI) evidence in humans that the auricular branch of the vagus nerve, via the cymba conchae (CC), projects to the nucleus of the solitary tract.

It has been shown by W. He et al., ${ }^{14}$ that auricular acupuncture plays a role in the vagal activity of autonomic functions of the cardiovascular, respiratory and gastrointestinal systems. Recent investigations have also shown that the vagal tone elicited by auricular acupuncture or auricular acupressure typically leads to a reduction in the heart rate and the blood pressure in athletes, ${ }^{15}$ as well as in vascular hypertensive patients, ${ }^{16}$ while in healthy volunteers, a significant decrease in the heart rate and a significant increase in the heart-rate variability have been shown. ${ }^{17}$

VNS could be an effective method for restoring diminished cardiac vagal activity in heart disease. ${ }^{18}$ In this regard, early and recent studies have proposed the use of a permanently implanted device with electrodes for VNS. ${ }^{1}$ However, to overcome the disadvantages of the surgical implantation of stimulation devices, newly developed non-invasive methods, including TES ${ }^{19-21}$ and electrical auricular-vagus stimulation, ${ }^{22}$ have been proposed to stimulate vagal afferents. All the applications of selective TES require electrodes with a high spatial selectivity, low impedance and safe reversible charge injection for stimulation. Thus, an understanding of the electrochemical mechanisms underlying the process of neural stimulation in the human body is important for developing stimulating devices, particularly those employing many electrodes. ${ }^{23,24}$ The selectivity of stimulation is exclusively dependent on localized charge delivery to specific populations of receptors. However, charge delivery is influenced by the electrode-tissue interface, where charge carriers transduce from electrons in the metal electrode to ions in the tissue. As a result, electrodes for selective TES face electrochemically harsh working conditions. However, it is imperative that any harmful reactions should not occur while injecting the required charge..$^{25,26}$

For electrical stimulation, different materials that support charge injection by capacitive and faradaic mechanisms are available. ${ }^{27}$ Pure platinum is commonly used as a stimulating electrode material because it can effectively supply high-density electrical charge to activate excitable tissue. ${ }^{28}$ High-purity platinum is nontoxic, insoluble in mineral and organic acids, and does not corrode or tarnish. In addition to its chemical inertness, platinum has many physical properties that are of great value for their use in the technology of stimulating electrodes. ${ }^{29-31}$ One of them is mechanical fitness, which is an important issue in the design of multi-electrode stimulation systems. Namely, pure platinum is a dense, malleable and the most ductile of pure metals, offering various processing possibilities to tailor electrode impedance. The specific properties of the platinum that were considered when the stimulating electrode is fabricated are tensile strength (124-165 MPa), elongation (30-40\%), hardness Vickers (40 HV), melting point $\left(1772{ }^{\circ} \mathrm{C}\right)$ and electrical resistivity (10.6 microhm-cm @ 20). As the most important, when platinum electrode is subjected to a predominantly cathodal stimulating pulse of $0.2 \mathrm{msec}$, the electrode can inject almost $3500 \mu \mathrm{C} / \mathrm{cm}^{2}$ when the cathodal pulses are interspersed with an anodic pulse. ${ }^{24-29}$ However, in electrical stimulation with a high charge density, irreversible changes could occur in the tissue. ${ }^{32}$ To efficiently control the interfacial voltage in selective electrical stimulation, a charge-balanced current stimuli with two phases of equal but opposite charges can be used. ${ }^{33,34}$ In this relation, to determine the efficiency and selectivity of the activation of the targeted receptors and neural fibres, characterizing the electrical impedance of the electrode-tissue interface is crucial in all TES applications.

Non-invasive electrical measurements of human skin using different impedance methods are widely used for various clinical applications, such as bio-electrical impedance analysis, electrical impedance tomography and the investigation of transdermal drug delivery, among others. ${ }^{35}$

The rationale for using the selective TES of afferent nerve fibres within the auricular branch of the vagus nerve is that an external ear is the only place on the surface of the human body where there is high density of afferent vagus nerve fibres compared with other regions of the head. ${ }^{36}$ Therefore, applying TES to afferent nerve fibres within the auricular branch of the vagus nerve can produce an effect similar to that of classic VNS in the modulation of the cardiac function.

The human skin consists of four layers with different thickness: the stratum corneum (SC) $(0.01-0.02 \mathrm{~mm})$; the epidermis $(0.03-0.13 \mathrm{~mm})$; the dermis $(1.1 \mathrm{~mm})$; and subcutaneous fat $(1.2 \mathrm{~mm}){ }^{37,38}$ Data on the electrical conductivity of layers in the skin can be found in the literature. ${ }^{39-41}$ The outermost layer, the SC, consists mostly of dried-out keratin layers and has a very low conductivity of $2 \times 10^{-5}(\mathrm{~S} / \mathrm{m})$. However, when an external electrical field is applied to the skin, the conductance increases significantly ${ }^{42}$ if the voltage drop across the SC exceeds approximately $30 \mathrm{~V} .{ }^{40}$ Lower voltage drops are too small for such electroporation. ${ }^{43}$ There are two pathways for the electrical current across the SC, namely, the lipid-corneocyte matrix and the preferred appendageal pathway. ${ }^{44,45}$ 
The second layer is the epidermis, which has a horizontal conductivity of 0.95 and a vertical conductivity of $0.15(\mathrm{~S} / \mathrm{m})$. The third layer is the dermis, which has a much higher horizontal conductivity of 2.57 and a vertical conductivity of $1.62(\mathrm{~S} / \mathrm{m})$. In the model, the dermis is considered a homogeneous volume conductor. The last layer is subcutaneous fat, which has a conductivity of $0.04(\mathrm{~S} / \mathrm{m}) .^{37,38,46} \mathrm{It}$ is presumed that skin at the CC contains a very thin fat layer even in overweight individuals.

This work is focused on applying selective TES to auricular branch fibres of the vagus nerve supplying the CC. ${ }^{36}$ Free nerve endings usually terminate in the junction of the epidermis and dermis, while the endings of the A $\delta$ fibres usually terminate in the dermis just underneath the epidermis. TES also stimulates other receptors, such as nociceptor Golgi-tendon receptors, Meissner corpuscles, Krause's end-bulbs and glomusbodies in the superficial regions of the CC..$^{36,47}$ They respond to the stimuli and send signals via slowly conducting afferent $\mathrm{A} \delta$ and $\mathrm{C}$ fibres to the spinal cord and the brain.

In the model, an area of the CC in which $100 \%$ of the innervation corresponds to the auricular branch of the vagus nerve is identified. ${ }^{14}$ Then, four sites at the $\mathrm{CC}$ are identified for monopolar, cathodal, selective TES.

The goals of the study were to model, design and test a four-channel system for applying TES to an auricular branch of the vagus nerve. One specific goal was to document a quantitative description of the stimulating cathode-skin interface at the external ear based on an equivalent circuit model (ECM) and measurements of the proprietary elements of the ECM. Another specific goal was to develop a multi-electrode plug for insertion into the external ear to enable repositioning of the stimulated area at the $\mathrm{CC}$ without the need to change the physical electrode location.

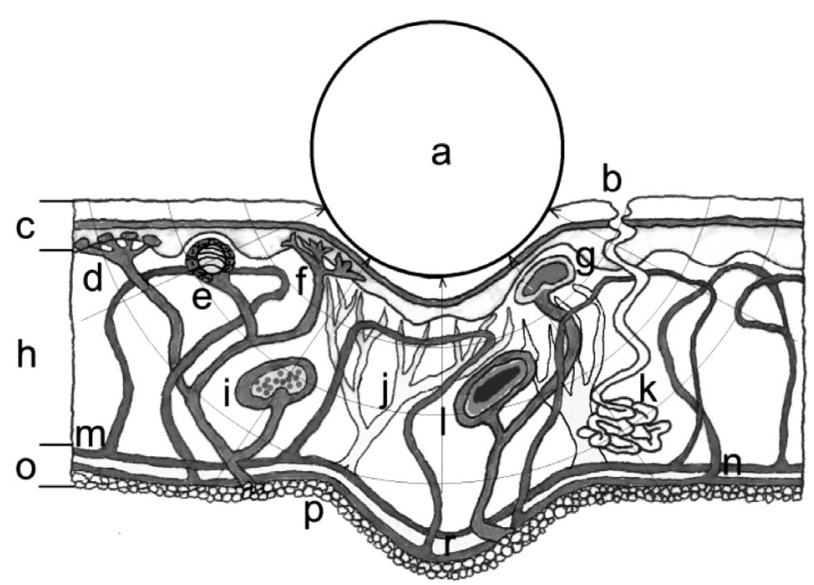

Figure 1: Schematic diagram of the skin structures that are exposed to an electric field containing populations of receptors and nerve endings under half of the globular cathode generated by radially dispersed $i_{\mathrm{c}}$ : a) cathode, b) sweat pore, c) epidermis, d) touch receptor, e) light touch receptor, f) pain receptor, g) cold receptor, h) dermis, i) pressure receptor, j) nerve endings, k) sweat gland, 1) heat receptor, $\mathrm{m}$ ) artery, n) vein, o) hypodermis, p) fatty layer, and r) sensory axons

\section{EXPERIMENTAL PART}

The design aspects have a crucial influence on the comfort and performance of TES electrodes. ${ }^{48}$ We propose a low-resistivity, small, globular platinum cathode and model its stimulation efficiency. The globule is pressed into the skin so the layers of the skin are bent into a basin surrounding about half of the globule to disperse the peak current radially, as shown schematically in Figure 1.

According to the finite-element model reported by N. Sha et al., ${ }^{49}$ the peak density of the stimulation current occurs immediately under the SC, where nerve endings presumably terminate. The cathodic electrical current $\left(i_{\mathrm{c}}\right)$ generates an electric field gradient (activation function) in the underlying tissue and stimulates certain populations of receptors and nerve endings under half of the globular cathode, as depicted in Figure 1.

Above a certain threshold, most of them are activated. ${ }^{46}$ The stimulus proposed in this work is a monopolar, cathodic-first, current-regulated, biphasic pair with a rectangular $i_{\mathrm{c}}$ and an exponentially decaying anodic component.

The most important part of the system is the plug to be inserted into the external ear that contains four platinum cathodes. The plugs are crafted using commercially available silicone plugs that are used by swimmers.

The cathodes are made of 5-mm-long pieces of platinum wire with a diameter of $0.3 \mathrm{~mm}(99.99 \%$ purity). The tool used for crafting the cathodes is a portable gas-welding device (Roxy Kit Plus, $3100{ }^{\circ} \mathrm{C}$, Rothenberger Industrial GmbH, Kelkenheim, Germany) with the following technical specifications: a peak flame temperature of up to $3100{ }^{\circ} \mathrm{C}$ using propane/butane (MAXI GAS 400) and oxygen. For crafting, a microburner is used. The flame is adjusted to burn uniformly (i.e., there is a balanced mixture of gases), and the size of the flame is adapted to suit the thickness and the heat conductivity of the wire. Then, the torch is applied close to one end of the piece held by tweezers, such that the flame is directed towards an end of the piece. As soon as the metal on the exposed side of the piece begins to melt, the globule begins to form due to the surface energy of the melted material. The resulting small globular platinum cathodes with a diameter of approximately 1.2 $\mathrm{mm}$ were then mechanically and galvanically connected to the insulated lead wires. Subsequently, they were attached onto the pre-defined sites of the silicone plugs. Finally, a silicone adhesive (ASC, Applied Silicone Corporation, Part No: 40064, MED RTV adhesive, implant grade, Santa Paula, California, U.S.A.) was deposited on each of the connecting sites to fix the electrodes within the silicone plugs. In practice, however, the geometric surface of the cathode deployed during stimulation is approximately one-half surface of the globule and is approximately $2.4 \mathrm{~mm}^{2}$. Table 1 represents the mecha- 
nical properties of the stimulating cathodes within the plugs.

Table 1: Mechanical properties of stimulating cathodes

\begin{tabular}{|c|c|c|c|c|}
\hline \multirow{2}{*}{$\begin{array}{c}\text { Globule } \\
\text { electrode }\end{array}$} & \multicolumn{2}{|c|}{$\begin{array}{c}\text { Globule diameter } \\
(\mathrm{mm})\end{array}$} & \multicolumn{2}{c|}{$\begin{array}{c}\text { Half globule surface } \\
\left(\mathrm{mm}^{2}\right)\end{array}$} \\
\cline { 2 - 5 } & Right plug & Left plug & Right plug & Left plug \\
\hline Red & 1.3 & 1.18 & 2.65 & 2.19 \\
\hline Yellow & 1.2 & 1.18 & 2.26 & 2.19 \\
\hline Black & 1.26 & 1.29 & 2.5 & 2.61 \\
\hline White & 1.3 & 1.2 & 2.65 & 2.26 \\
\hline Average & 1.26 & 1.21 & 2.51 & 2.31 \\
\hline
\end{tabular}

The common electrode (anode) is crafted using a 3-mm-thick, 300-mm-long and 25-mm-wide ribbon made of highly water-absorptive sponge that is stitched below the stainless-steel mesh and Velcro tape. The geometric surface of the anode is approximately $7500 \mathrm{~mm}^{2}$. Since the wet anode touches the skin directly, it is considered a homogeneous conductive solution that is approximately $5 \mathrm{~mm}$ thick. Figure 2 shows both the (a) crafted plugs with cathodes and the (b) crafted anode.

During the measurements, each of the plugs is pushed into an external ear using a force of approximately $2.5 \mathrm{~N}$ produced by a latex sponge pad mounted on a soft spring, as shown in Figure 2c. To measure the relative temperature variations within the plug, the micro-BetaCHIP temperature probe (Measurement Spe-
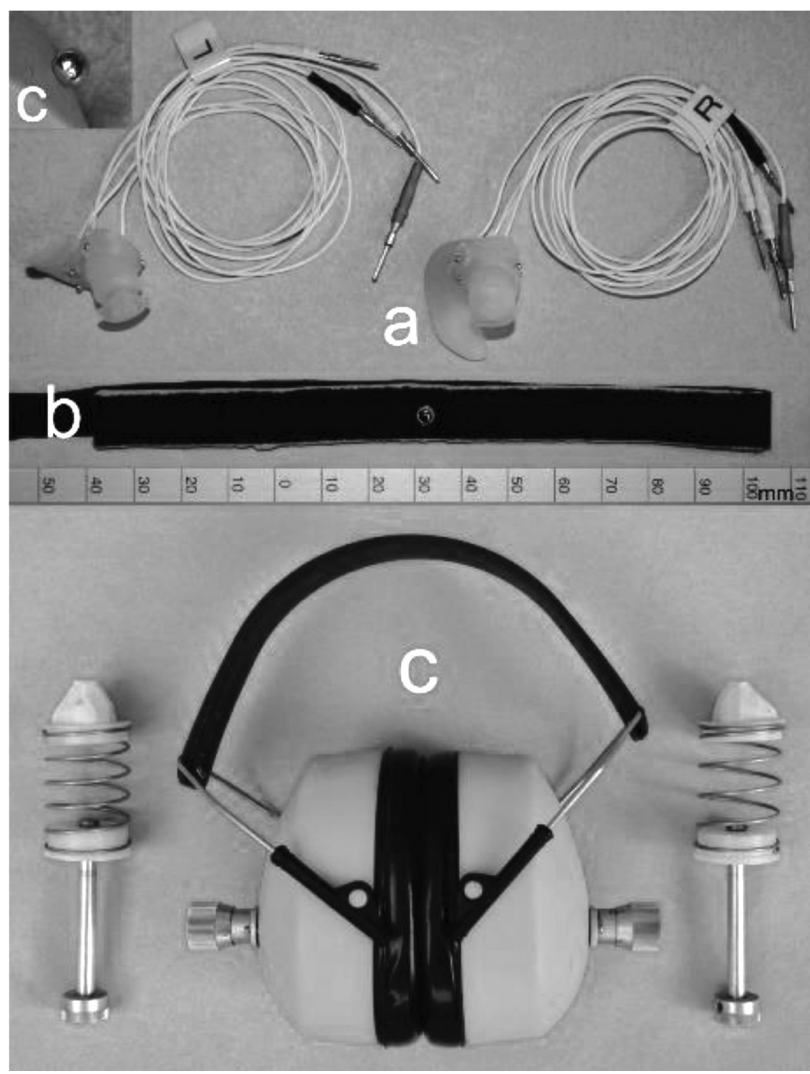

Figure 2: a) Stimulating plugs, b) common anode, c) dummy headphones cialties, Inc., a TE Connectivity Company, Shrewsbury, MA 01545, U.S.A.) is inserted into the centre of the silicone plug.

Figure 3 shows a set-up for the selective TES of an auricular branch of the vagus nerve. Figure 3a shows a custom-made four-channel electrical stimulator that provides asymmetrical biphasic current pulses with the following parameters: a 1 -second pulse train at $f=25 \mathrm{~Hz}$; an amplitude of stimulation $\left(i_{\mathrm{c}}\right.$ ) between 0 and $60 \mathrm{~mA}$; and a cathodic component $\left(t_{\mathrm{c}}\right)$ width of $200 \mu \mathrm{s}$. The stimulus pulse train, once triggered, began at a pulse width of $25 \mu \mathrm{s}$ and linearly increased to $200 \mu$ s during the stimulation duration. This mode of stimulation allowed a gradual rather than an abrupt onset of TES and acceptable comfort for the subjects. TES can be synchronized by breathing using a custom-designed diaphragm sensor based on a piezo sensing element or by heart rate using a low-cost fingertip pulse oximeter (both not shown in this paper).

Figure 3b shows a left and right switching module with five colour-coded pins for connecting the cathodes and the anode. The module allows the patient to select between continuous or manually triggered stimulation. Figure 3c shows a module that enables measurement of both the voltage response (VR) on a particular cathode with respect to the anode and $i_{\mathrm{c}}$ using a voltage drop across the precision serial resistor of $10 \Omega$ in the module.

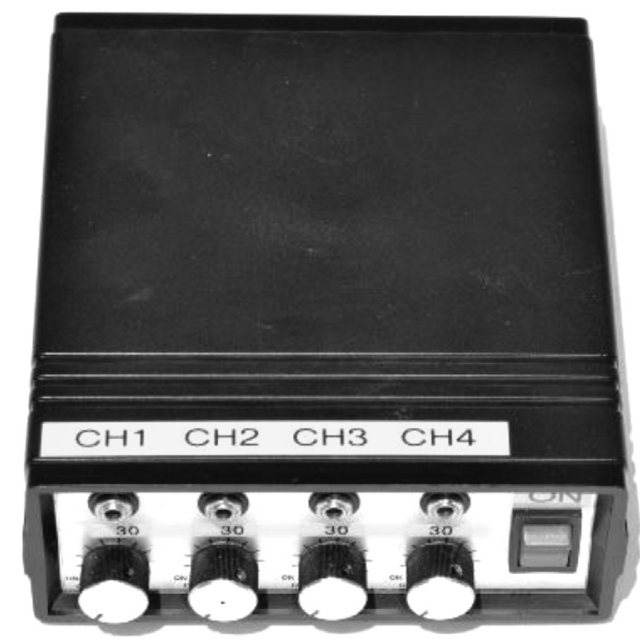

a

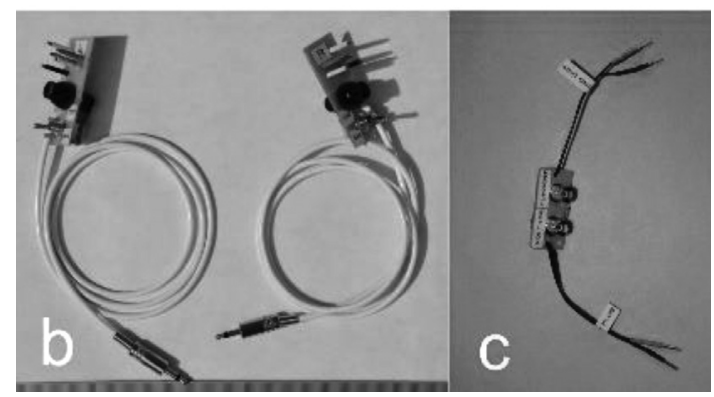

Figure 3: Set-up for the selective TES of an auricular branch of the vagus nerve: a) Four-channel TES stimulator, b) switching unit, c) module for measuring capacitance and impedance 
The electrode performance was assessed in a 62 -year-old male patient with angina pectoris. The protocols of the measurements were approved by the National Medical Ethics Committee, Ministry of Health, Republic of Slovenia (Tel: +386 0147869 13, http://www.kme-nmec.si/kontakt/, Unique Identifier No. 0120-297/2018/6). The subject was informed about the purpose and the procedures of the study.

The anode was placed at the middle of the neck, while the plug containing the cathodes was placed into the external ear such that each cathode was in contact with the corresponding site at the CC. The anode was connected to ground, and the cathode was connected as the $i_{\mathrm{c}}$ source.

To assess the absolute impedance magnitude $|Z|$ of the cathodes in selective TES, a simplified ECM of both interfaces, i.e., the interface at the cathode and the anode, was proposed using a modified Randles cell model, ${ }^{50}$ as shown in Figure 4a. The interface at the cathode shown in Figure $4 \mathbf{a}$ consists of skin resistance $R_{\mathrm{sc}}$ in series with the parallel combination of the capacitance $C_{\mathrm{pc}}$ and resistance $R_{\mathrm{pc}}$. Similarly, the interface at the anode, also shown in Figure $4 \mathbf{a}$, consists of skin resistance $R_{\mathrm{sa}}$ in series with the parallel combination of capacitance $C_{\mathrm{pa}}$ and resistance $R_{\mathrm{pa}} ; R_{\text {body }}$ is the resistance parallel to the ECM.

The ensemble capacitance $C_{\mathrm{p}}$ consists of charges in both the electrodes and ions in the skin below them, while the ensemble resistance $R_{\mathrm{p}}$ represents current flow at the electrode-skin interfaces. The $R_{\mathrm{s}}$, represents the

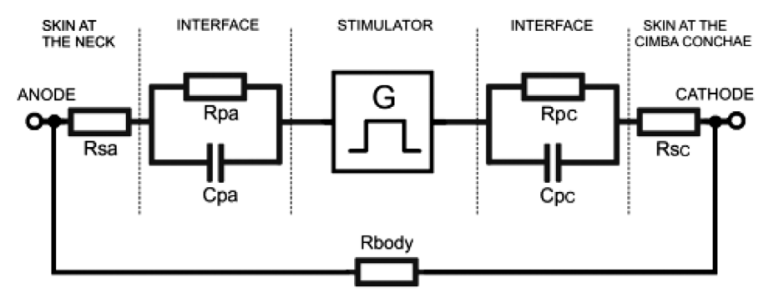

a

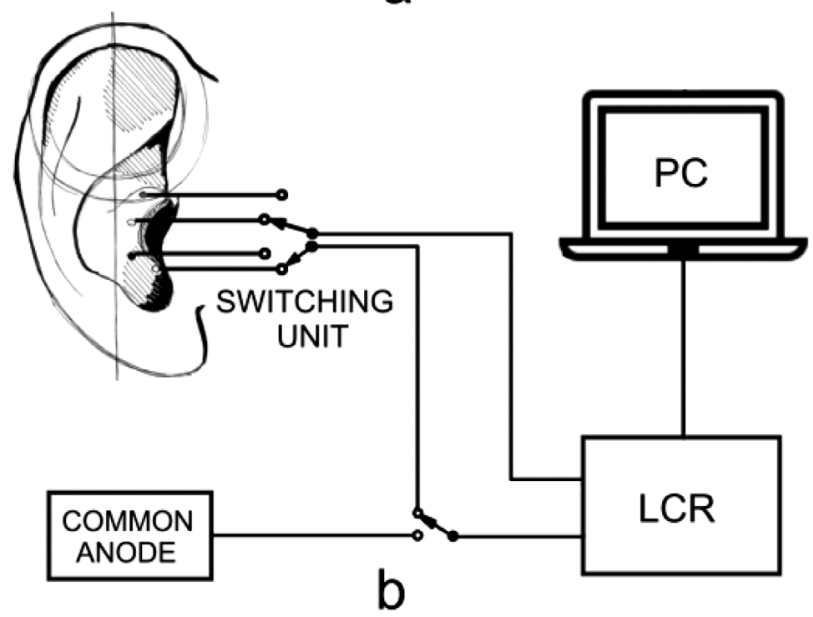

Figure 4: a) ECM elements of the electrode-skin interface for the anode and cathode, b) schematic diagram of the cathode impedance and capacitance measurements ensemble resistance of the skin between the cathode and the anode, the resistance of the cables and wires connecting the electrodes and the stimulator, and $R_{\text {body }}$.

To determine elements of the ECM, representing the actual load attached to the electrical stimulator, the LCR meter (AT2816A Precision Digital LCR Meter, Changzhou Applent Instruments, Ltd., Jiangsu, China), was used. The instrument measured the following four parameters of the actual load: $C_{\mathrm{a}}, R_{\mathrm{a}},|Z|_{\mathrm{a}}$ and $\theta_{\mathrm{a}}$.

The power spectrum density (PSD) of the stimulation pulse (not shown in this paper) was also considered. In this regard, two main peaks, one at approximately $1 \mathrm{kHz}$ and the other at approximately $2.5 \mathrm{kHz}$, were used as frequencies where $|Z|_{\mathrm{a}}$ and ECM elements were measured.

Then, in a patient, the $C a, R_{\mathrm{a}},|Z|_{\mathrm{a}}$ and $\theta_{\mathrm{a}}$ between each out of the four cathodes located at the CC in the left and right ears and the anode were measured. A schematic diagram of the $C_{\mathrm{a}}, R_{\mathrm{a}},|Z|_{\mathrm{a}}$ and $\theta_{\mathrm{a}}$ measurements is shown in Figure $\mathbf{4 b}$. Before placement of the plug into the external ear, the skin area at the $\mathrm{CC}$ was cleaned with $75 \%$ isopropyl alcohol, as was the particular skin area at the neck before placement of the anode onto the neck. The above-mentioned variables were measured once at a frequency of $1 \mathrm{kHz}$ and once at a frequency of $2.5 \mathrm{kHz}^{51}$ with the following settings:

Source resistance: $\quad 50 \Omega$

Testing excitation voltage: $1 \mathrm{~V}$

Trigger:

Speed:

Accessory:

manual

$10 \mathrm{t} / \mathrm{s}, 32$ time average

ATL601 test fixture.

To determine the $C_{\mathrm{a}}, R_{\mathrm{a}},|Z|_{\mathrm{a}}$ and $\theta_{\mathrm{a}}$ of the anode separately, the anode was placed on a 300 -mm-long and 25-mm-wide ribbon made of stainless steel cleaned with $75 \%$ isopropyl alcohol. A bandage was used to maintain good contact between the anode and the stainless-steel plate. The variables were measured again at the two frequencies, i.e., $1 \mathrm{kHz}$ and $2.5 \mathrm{kHz}$, using the aforementioned settings of the LCR meter. The charge injected into the specific site at the CC can be calculated as follows:

$Q_{\mathrm{c}}=i_{\mathrm{c}} \times t_{\mathrm{c}} \times$ number of charge squares $=$

$=4 \mathrm{~mA} \times 10 \mu \mathrm{s} \times 145$ charge squares $=5.8 \mu \mathrm{C}$

where the surface under the cathodic part of the biphasic stimulus pulse pair was divided into the 145 equal charge squares.

Half of the cathode surface area $A_{\mathrm{c}}$ calculated as an average of all eight globules with an average diameter $d$ in the right and left plugs is as follows:

$$
A_{\mathrm{c}}=\pi \times d^{2} \div 8=2.41 \mathrm{~mm}^{2}
$$

The stimulating charge density $C_{\mathrm{d}}$ considering the abovementioned calculations is as follows:

$C_{\mathrm{d}}=\frac{Q_{\mathrm{c}}}{A_{\mathrm{c}}}=5.8 \mu \mathrm{C} \div 2.41 \mathrm{~mm}^{2}=$

$=2.4 \mu \mathrm{As} / \mathrm{mm}^{2}=2.4 \mu \mathrm{C} / \mathrm{mm}^{2}$ 
J. ROZMAN et al.: A SYSTEM FOR THE MULTI-CHANNEL TRANSCUTANEOUS STIMULATION ...

Table 2: $C_{\mathrm{a}}, R_{\mathrm{a}},|Z|_{\mathrm{a}}$ and $\theta_{\mathrm{a}}$ of actual load attached to the electrical stimulator measured at $1 \mathrm{kHz}$

\begin{tabular}{|c|c|c|c|c|c|c|c|c|}
\hline \multirow{2}{*}{$\begin{array}{c}\text { Globule } \\
\text { electrode }\end{array}$} & \multicolumn{2}{|c|}{ Impedance $\left.Z\right|_{\mathrm{a}}(\mathrm{k} \Omega)$} & \multicolumn{2}{c|}{ Capacitance $C_{\mathrm{a}}(\mathrm{nF})$} & \multicolumn{2}{c|}{ Phase angle $\theta_{\mathrm{a}}\left(^{\circ}\right)$} & \multicolumn{2}{c|}{ Resistance $R_{\mathrm{a}}(\mathrm{k} \Omega)$} \\
\cline { 2 - 10 } & Right plug & Left plug & Right plug & Left plug & Right plug & Left plug & Right plug & Left plug \\
\hline Red & 46.55 & 60.58 & 1.39 & 1.26 & -24.03 & -28.67 & 50.96 & 69.05 \\
\hline Yellow & 32.31 & 33.65 & 2.37 & 1.86 & -28.84 & -23.85 & 36.9 & 36.7 \\
\hline Black & 67.21 & 36.15 & 1.01 & 1.5 & -25.27 & -19.9 & 74.32 & 38.44 \\
\hline White & 25.93 & 31.12 & 2.57 & 1.69 & -24.8 & -19.34 & 28.57 & 33 \\
\hline Average & 43 & 40.37 & 1.83 & 1.57 & -25.73 & -22.94 & 47.68 & 44.29 \\
\hline
\end{tabular}

Table 3: $C_{\mathrm{a}}, R_{\mathrm{a}},|Z|_{\mathrm{a}}$ and $\theta_{\mathrm{a}}$ of actual load attached to the electrical stimulator measured at $2.5 \mathrm{kHz}$

\begin{tabular}{|c|c|c|c|c|c|c|c|c|}
\hline \multirow{2}{*}{$\begin{array}{l}\text { Globule } \\
\text { electrode }\end{array}$} & \multicolumn{2}{|c|}{ Impedance $|Z|_{\mathrm{a}}(\mathrm{k} \Omega)$} & \multicolumn{2}{|c|}{ Capacitance $C_{\mathrm{a}}(\mathrm{nF})$} & \multicolumn{2}{|c|}{ Phase angle $\theta_{\mathrm{a}}\left({ }^{\circ}\right)$} & \multicolumn{2}{|c|}{ Resistance $R_{\mathrm{a}}(\mathrm{k} \Omega)$} \\
\hline & Right plug & Left plug & Right plug & Left plug & Right plug & Left plug & Right plug & Left plug \\
\hline Red & 27.66 & 16.92 & 1.11 & 1.27 & -28.9 & -18.66 & 31.6 & 16.9 \\
\hline Yellow & 26.72 & 22.97 & 1.42 & 1.28 & -36.6 & -27.56 & 33.3 & 25.91 \\
\hline Black & 21.33 & 15.63 & 2.08 & 1.55 & -44.2 & -22.4 & 29.75 & 16.01 \\
\hline White & 25.81 & 17.33 & 1.39 & 1.25 & -34.4 & -21.2 & 31,28 & 17.1 \\
\hline Average & 25.38 & 18.21 & 1.5 & 1.33 & -36.02 & -22.45 & 31.48 & 18.98 \\
\hline
\end{tabular}

The anodic charge density $A_{\mathrm{d}}$ is as follows:

$$
A_{\mathrm{d}}=\frac{Q_{\mathrm{c}}}{A_{\mathrm{c}}}=5.8 \mu \mathrm{C} \div 7,500 \mathrm{~mm}^{2}=0.773 \mathrm{nC} / \mathrm{mm}^{2}
$$

To assess the VR at a particular cathode with respect to the anode and $i_{\mathrm{c}}$, a voltage drop across the precision serial resistor attached at the output of the stimulating channel, a dual-channel digital oscilloscope (TekScope, Tektronix), was used. In this way, a step-down converter is avoided when assessing the VR.

The stimulating intensity $i_{\mathrm{c}}$, pulse width and frequency were set at the level for which some level of discomfort at the particular deployed cathode is produced. Charge transferred by the cathode was the same as the charge transferred by the anode, while the charge densities differed significantly. The charge transferred by either of the electrodes $Q_{\mathrm{c}}$ can be obtained from the $i_{\mathrm{c}}$ waveform using a simple method of calculating the surface under the cathodic component of the stimulating pulse pair that was divided into the corresponding number of equal charge squares.

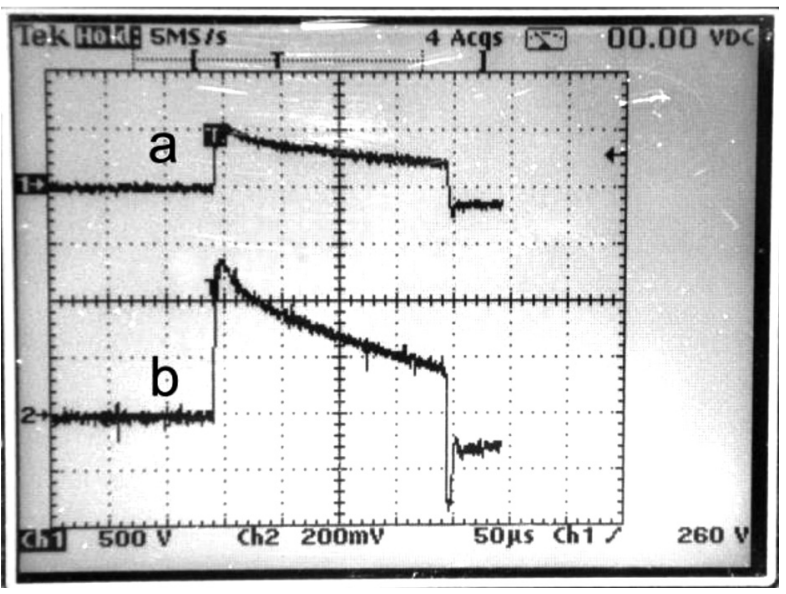

Figure 5: Traces of a stimulating pulse: a) VR and b) $i_{\mathrm{c}}$

\section{RESULTS}

Tables 2 and 3 represent elements of the ECM, corresponding to an actual load attached to the electrical stimulator when measured at two different frequencies, as shown in Figure 4b. More precisely, Table 2 represents the $C_{\mathrm{a}}, R_{\mathrm{a}},|Z|_{\mathrm{a}}$ and $\theta_{\mathrm{a}}$ of the interface between each out of the four cathodes located at the CC in the left and right ears and the anode measured at $1 \mathrm{kHz}$.

Furthermore, Table 3 represents the $C_{\mathrm{a}}, R_{\mathrm{a}},|Z|_{\mathrm{a}}$ and $\theta_{\mathrm{a}}$ of the interface between each out of the four cathodes located at the $\mathrm{CC}$ in the left and right ears and the anode measured at $2.5 \mathrm{kHz}$.

Finally, Table 4 represents the $C_{\mathrm{a}}, R_{\mathrm{a}},|Z|_{\mathrm{a}}$ and $\theta_{\mathrm{a}}$ of the interface between the wet anode and stainless-steel plate measured at a frequency of $1 \mathrm{kHz}$ and $2.5 \mathrm{kHz}$.

Table 4: $C_{\mathrm{a}}, R_{\mathrm{a}},|Z|_{\mathrm{a}}$ and $\theta_{\mathrm{a}}$ of of the anode measured at $1 \mathrm{kHz}$ and 2.5 $\mathrm{kHz}$

\begin{tabular}{|c|c|c|c|c|}
\hline $\begin{array}{c}\text { Frequency } \\
(\mathrm{kHz})\end{array}$ & $\begin{array}{c}\text { Impedance } \\
|Z|_{\mathrm{a}}(\Omega)\end{array}$ & $\begin{array}{c}\text { Capacitance } \\
C_{\mathrm{a}}(\mathrm{nF})\end{array}$ & $\begin{array}{c}\text { Phase angle } \\
\theta_{\mathrm{a}}\left({ }^{\circ}\right)\end{array}$ & $\begin{array}{c}\text { Resistance } \\
R_{\mathrm{a}}(\Omega)\end{array}$ \\
\hline 1 & 51.036 & 283.756 & -5.2206 & 51.2483 \\
\hline 2.5 & 48.789 & 64.807 & -2.8468 & 48.8489 \\
\hline
\end{tabular}

The traces of VR and $i_{\mathrm{c}}$, measured when the stimulating pulse was applied at a particular site of the $\mathrm{CC}$ via a cathode, are shown in Figure 5.

\section{DISCUSSION}

The present article reviews the methodology of the development of a four-channel system for applying TES to an auricular branch of the vagus nerve. Specifically, the electrical characteristics of a platinum cathode within the four-electrode plug to stimulate the $\mathrm{CC}$ region selectively are investigated. The ultimate objective of this study, however, was to develop and fabricate a system for an efficient, safe and selective transcutaneous 
VNS that would advance the development of neural prostheses in humans.

By stimulating the auricular branch of the vagus nerve, we presumably increase the flow of impulses travelling towards the nucleus of the solitary tract (NTS). Consequently, activation of the efferents in the vagus nerve, which is mediated through the nucleus ambiguus (NA) and dorsal vagus nucleus (DVN), is reflected by a change in the heart rhythm. The synapses between the neurons in the caudal ventrolateral medulla (CVLM) and the rostral part of the ventrolateral medulla (RVLM) can also participate in modulating the sympathetic tone. The activation of fibres in the CVLM is believed to inhibit the excitatory neurons of the RVLM, which in turn reduces the frequency of the action potentials travelling through the sympathetic nerves. One controversy on the specificity of auricular stimulation points is that similar patterns of cardiovascular responses could be obtained by stimulating the different areas of the auricle; thus, the theory of a highly specific functional map in the ear is not supported. ${ }^{52}$

We presume that $i_{\mathrm{c}}$ spreads radially from half of the globular cathode such that nerve endings can be activated within the surrounding volume. In fact, nerve endings can have a complex geometric shape and orientation, so the radial spreading of $i_{\mathrm{c}}$ is presumably more effective in TES than spreading in a single direction. However, to stimulate nerve fibres, the activation function must be positive; otherwise, only specific receptors are activated.

The results represented in Tables $\mathbf{2}$ and $\mathbf{3}$ show that all the averaged elements of the ECM that correspond to an actual load attached to the electrical stimulator, i.e., the capacitance $C_{\mathrm{a}}$, resistance $R_{\mathrm{a}}$, impedance $|Z|_{\mathrm{a}}$ and $\theta_{\mathrm{a}}$ of the interface between the cathodes and the anode, are higher in the right plug, where all the cathodes have slightly larger surfaces than the cathodes in the left plug. These results also show that all the aforementioned averaged variables have larger values when measured at $1 \mathrm{kHz}$ than when measured at $2.5 \mathrm{kHz}$.

Table 4 shows the elements measured at the interface between the wet anode and the stainless-steel plate; all of these values are lower at a frequency of $2.5 \mathrm{kHz}$ than at 1 $\mathrm{kHz}$. The absolute impedance magnitude $|Z|$ is reduced from $51.036 \mathrm{k} \Omega$ at $1 \mathrm{kHz}$ to $48.789 \mathrm{k} \Omega$ at $2.5 \mathrm{kHz}$. However, it is considered that the contribution of the large common anode to the aforementioned elements is orders of magnitude larger but is constant as it does not depend on changes in the pressure on the cathodes.

The main difference between our study and those of others is related to the development of a four-electrode silicone plug that enables both selective TES at the CC and multiple repositioning of the stimulated site without the need to change the physical electrode's location. Another difference from previous studies is the modelling and development of the platinum cathode, which could be considered as a microelectrode. In this aspect, special attention during the development was focused onto the requirement of good cathode-skin contact, such that no high $i_{\mathrm{c}}$ density peaks can occur because of the small contact area. The greatest concern in dimensioning the cathodes was therefore to provide effective activation at the targeted locations of the CC with the least pain and without permanent skin damage (burns) and irritation.

The greatest weakness of the system is a significant dependence of the ECM elements on the force used to push the plug into an external ear. Namely, all the elements of the actual load, i.e., $C_{\mathrm{a}}, R_{\mathrm{a}},|Z|_{\mathrm{a}}$ and $\theta_{\mathrm{a}}$, vary with variations of the pressure that is applied on the globule as the layers of the skin bent into a basin surrounding corresponding surface of the globule. To minimise this dependence, each of the plugs should be pushed into an external ear using a force of approximately $2.5 \mathrm{~N}$ provided by the spring within the dummy headphones.

Another weakness of the model is that monopolar, very selective TES drives the current from the cathode in the preferred direction, which is rectangular according to the skin, and significantly less current spreads in other directions. As a result, a limited population of nerve fibres are stimulated. It is important to note that recording ECG signals during stimulation is possible, but artefacts with very low amplitude remain. Namely, highly dispersed paths of electrical current are located above the anode such that they have some influence onto the ECG recording electrodes that are attached to the patient's chest well below the anode.

Further directions of our work could be the following:

- use of a more elaborate finite-element model based on the anatomical structure of the $\mathrm{CC}$ as well as electrophysiology to reveal the mechanism of the electrical stimulation of nerve endings,

- assess the cathode interfaces using an electrochemical impedance spectroscopy technique,

- develop the finite-element model of the cathode to analyse what mechanisms cause stimulation discomfort at the cathode,

- improve the electrode-skin contact of the stimulating electrodes,

- test the in-vivo selectivity of the TES for afferent nerve fibres within the auricular branch of the vagus nerve.

\section{CONCLUSIONS}

The specific goal to quantitatively describe the electrode-skin interface as assessed using measurements performed at four specific sites at the CC area of the left and right external ears in a 62-year-old male patient with angina pectoris was achieved.

The goal to develop a four-electrode plug enabling multiple repositioning of the stimulated area without the need to change the physical electrode location was achieved. 
A charge density released at any of the cathodes of $C_{\mathrm{d}}=2.4 \mu \mathrm{C} / \mathrm{mm}^{2}$ was sufficiently high to stimulate subcutaneous neural structures. An anodic charge density of $A_{\mathrm{d}}=0.773 \mathrm{nC} / \mathrm{mm}^{2}$ was too low to cause any stimulating effects in the neck muscles.

All the elements of the ECM that represent the electrode-skin interface significantly depended on the pressure applied to the plug, particularly each of the four platinum cathodes in close contact with the sites of the CC. Therefore, the pressure should remain as steady as possible during the entire period of the TES.

\section{Acknowledgment}

The authors would like to acknowledge the support of grant P3-0171 from the Slovenian Research Agency, Ministry of Education, Science and Sport, Ljubljana, Republic of Slovenia.

\section{REFERENCES}

${ }^{1}$ A. M. Bilgutay, I. M. Bilgutay, F. K. Merkel, C. W. Lillehei, Vagal tuning. A new concept in the treatment of supraventricular arrhythmias, angina pectoris, and heart failure, J. Thorac. Cardiovasc. Surg., 56 (1968), 71-82

${ }^{2}$ J. P. Beekwilder, T. Beems, Overview of the clinical applications of vagus nerve stimulation, J. Clin. Neurophysiol., 27 (2010), 130-8, doi:10.1097/WNP.0b013e3181d64d8a

${ }^{3}$ A. P. Amar, M. L. Levy, C. Y. Liu, M. L. J. Apuzzo, Vagus nerve stimulation, Neuromodulation, Academic Press, London 2009, 625-37

${ }^{4}$ R. H. Howland, Vagus nerve stimulation, Curr. Behav. Neurosci. Rep., 1 (2014) 64-73, doi:10.1007/s40473-014-0010-5

${ }^{5}$ G. M. de Ferrari, P. J. Schwartz, Vagus nerve stimulation: from pre-clinical to clinical application: challenges and future directions, Heart Fail Rev., 16 (2010) 2, 195-203, doi:10.1007/s10741-0109216-0

${ }^{6}$ S. Dietrich, J. Smith, C. Scherzinger, K. Hofmann-Preiß, T. Freitag, A. Eisenkolb, R. Ringler, A novel transcutaneous vagus nerve stimulation leads to brainstem and cerebral activations measured by functional MRI, Biomed. Tech. Biomed. Eng., 53 (2008) 3, 104-11, doi:10.1515/BMT.2008.022

${ }^{7}$ L. Gori, F. Firenzuoli, Ear acupuncture in European traditional medicine, Evid Based Complement. Altern. Med., 4 (2007) 1, 13-6, doi:10.1093/ecam/nem106

${ }^{8}$ P. M. Nogier, External ear: Zones and reflex points [in French], Bull. Soc. d'Acupunct., 20 (1956) 51-7.

${ }^{9}$ P. M. Nogier, From auriculotherapy to auriculomedicine, Moulinsles-Metz, Maisonneuve 1983, 231

${ }^{10}$ X. Y. Gao, Y. H. Li, K. Liu, P. J. Rong, H. Ben, L. Li, B. Zhu, S- P. Zhang, Acupuncture-like stimulation at auricular point Heart evokes cardiovascular inhibition via activating the cardiac-related neurons in the nucleus tractus solitarius, Brain Res., 1397 (2011) 19-27, doi:10.1016/j.brainres.2011.04.034

${ }^{11}$ M. T. Cabioglu, A glance at the acupuncture point from the perspective of current technology, Open Access Library Journal, 3 (2016) 1-5, doi:10.4236/oalib.1102237

${ }^{12}$ H. G. Kho, E. Robertson, The mechanisms of acupuncture analgesia: review and update Am. J. Acupunct., 25 (1997) 261-81

${ }^{13}$ E. Frangos, J. Ellrich, B. R. Komisaruk, Non-invasive access to the vagus nerve central projections via electrical stimulation of the external ear: fMRI evidence in humans, Brain Stimul., 8 (2015) 3, 624-36, doi:10.1016/j.brs.2014.11.018
${ }^{14}$ W. He, X. Wang, H. Shi, H. Shang, L. Li, X. Jing, B. Zhu, Auricular acupuncture and vagal regulation, Evid. Based Complement. Altern. Med., 2012 (2012), doi:10.1155/2012/786839

${ }^{15}$ Z. P. Lin, Y. H. Chen, C. Fan, H. J. Wu, L. W. Lan, J. G. Lin, Effects of auricular acupuncture on heart rate, oxygen consumption and blood lactic acid for elite basketball athletes, Am. J. Chin. Med., 39 (2011) 6, 1131-8, doi:10.1142/S0192415X11009457

${ }^{16}$ H. Huang, S. Liang, Acupuncture at otoacupoint heart for treatment of vascular hypertension, J. Tradit. Chin. Med., 12 (1992) 2, 133-6

${ }^{17}$ X. Y. Gao, L. Wang, I. Gaischek, Y. Michenthaler, B. Zhu, G. Litscher, Brain-modulated effects of auricular acupressure on the regulation of autonomic function in healthy volunteers, Evid. Based Complement. Altern. Med., 2011 (2012) 1-8, doi:10.1155/2012/ 714391

${ }^{18}$ J. Armour, Peripheral autonomic neuronal interactions in cardiac regulation, Neurocardiology, Oxford University Press, New York 1994, 219-49

${ }^{19}$ J. Ellrich, Transcutaneous vagus nerve stimulation, Eur. Neurol. Rev., 6 (2011) 4, 254-6, doi:10.17925/ENR.2011.06.04.254

${ }^{20}$ T. Kraus, K. Hösl, O. Kiess, A. Schanze, J. Kornhuber, C. Forster, BOLD fMRI deactivation of limbic and temporal brain structures and mood enhancing effect by transcutaneous vagus nerve stimulation, J. Neural. Transm., 114 (2007) 1485-93, doi:10.1007/s00702-0070755-z

${ }^{21}$ E. C. G. Ventureyra, Transcutaneous vagus nerve stimulation for partial onset seizure therapy, Child's Nerv. Syst., 16 (2000) 2, 101-2, doi:10.1007/s003810050021

${ }^{22}$ A. C. Yang, J. G- Zhang, P. J. Rong, G. G. Liu, N. Chen, B. Zhu, A new choice for the treatment of epilepsy: electrical auricula-vagusstimulation, Med. Hypothese, 77 (2011) 2, 244-5, doi:10.1016/ j.mehy.2011.04.021

${ }^{23}$ P. F. Johnson, L. L. Hench, An in vitro model for evaluating neural stimulating electrodes, J. Biomed. Mater. Res., 10 (1976) 6, 907-28, doi:10.1002/jbm.820100609

${ }^{24} \mathrm{D}$. R. Merrill, The electrochemistry of charge injection at the electrode/tissue interface, Implantable Neural Prostheses 2, Springer, New York 2010, 85-138, doi:10.1007/978-0-387-98120-8_4

${ }^{25}$ L. S. Robblee, T. L. Rose, Electrochemical guidelines for selection of protocols and electrode materials for neural stimulation, Neural Prostheses: Fundamental Studies, Prentice-Hall, Englewood Cliffs 1990, 25-66

${ }^{26}$ E. Gileadi, E. Kirowa-Eisner, J. Penciner, Interfacial electrochemistry: an experimental approach, Reading, Massachusetts: AddisonWesley Pub. Co., Advanced Book Program, 1975

${ }^{27}$ L. A. Geddes, R. Roeder, Criteria for the selection of materials for implanted electrodes, Ann. Biomed. Eng., 31 (2003) 7, 879-90, doi:10.1114/1.1581292

${ }^{28}$ S. B. Brummer, M. J. Turner, Electrochemical considerations for safe electrical stimulation of the nervous system with platinum electrodes, IEEE Trans. Biomed. Eng., BME-24 (1977) 1, 59-63. doi:10.1109/ TBME.1977.326218

${ }^{29}$ Official Journal of the European Union, Commission directive 2004/96/EC, Brussels

${ }^{30}$ E. P. Unskov, W. Johnson, V. L. Kolmogorov, E. A. Popov, Y. Safarov, R. Venter, H. Kudo, K. Osakada, H. Pugh, R. Sowerby R, Theory of plastic deformations of metals, Mashinostroenie, Moscow 1983

${ }^{31}$ B. T. Biggs, S. S. Taylor, E. van der Lingen, The hardening of platinum alloys for potential jewellery application, Platin Metals Rev., 49 (2005) 1, 2-15, doi:10.1595/147106705x24409

${ }^{32}$ B. Onaral, H. H. Sun, H. P. Schwan, Electrical properties of bioelectrodes, IEEE Trans. Biomed. Eng., BME-31 (1984) 12, 827-32, doi:10.1109/TBME.1984.325245

${ }^{33}$ S. F. Cogan, Neural stimulation and recording electrodes, Ann. Rev. Biomed. Eng., 10 (2008) 275-309, doi:10.1146/annurev.bioeng.10. 061807.160518 
${ }^{34}$ E. M. Hudak, J. T. Mortimer, H. B. Martin, Platinum for neural stimulation: voltammetry considerations, J. Neural. Eng., 7 (2010) 2, 026005, doi:10.1088/1741-2560/7/2/026005

${ }^{35}$ E. F. Prokhorov, J. González-Hernández , Y. V. Vorobiev, E. Morales-Sánchez, T. E. Prokhorova, G. Z. L. de Larrea, In vivo electrical characteristics of human skin, including at biological active points, Med. Biol. Eng. Comput., 38 (2000) 5, 507-11

${ }^{36}$ E. T. Peuker, T. J. Filler, The nerve supply of the human auricle, Clin. Anat., 15 (2002) 1, 35-7, doi:10.1002/ca.1089

${ }^{37}$ J. Sandby-Møller, T. Poulsen, H. C. Wulf, Epidermal thickness at different body sites: relationship to age, gender, pigmentation, blood content, skin type and smoking habits, Acta Derm. Venereol., 83 (2003) 6, 410-3, doi:10.1080/00015550310015419

${ }^{38} \mathrm{http}$ ///hearinghealthmatters.org/waynesworld/2014/human-ear-canal-vii, 21.07.2014

${ }^{39}$ T. Keller, A. Kuhn, Electrodes for transcutaneous (surface) electrical stimulation, J. Autom. Control., 18 (2008) 2, 35-45, doi:10.2298/ JAC0802035K

${ }^{40}$ Y. A. Chizmadzhev, A. V. Indenbom, P. I. Kuzmin, S. V. Galichenko, J. C. Weaver, R. O. Potts, Electrical properties of skin at moderate voltages: contribution of appendageal macropores, Biophys. J., 74 (2 Pt 1) (1998) 843-56, doi:10.1016/S0006-3495(98)74008-1

${ }^{41}$ A. Kuhn, Modeling transcutaneous electrical stimulation, Diss. ETH No. 17948, ETH Zurich, Zurich 2008, 211

${ }^{42}$ P. M. Elias, Epidermal lipids, barrier function, and desquamation, J. Invest. Dermatol., 80 (1983) 1, 44s-9s, doi:10.1038/jid.1983.12

${ }^{43}$ I. G. Abidor, V. Arakelian, V. Pastushenko, M. Tarasevich, L. Chernomordik, Electrical breakdown of lipid bilayer membranes. Doklady Akademii nauk SSSR, 240 (1978) 3, 733-6

${ }^{44} \mathrm{~S}$. Grimnes, Pathways of ionic flow through human skin in vivo, Acta Derm. Venereol., 64 (1984) 2, 93-8
${ }^{45}$ R. Ivanic, I. Novotny, V. Rehacek, V. Tvarozek, M. Weis, Thin film non-symmetric microelectrode array for impedance monitoring of human skin, Thin Solid Films, 433 (2003) 1-2, 332-336, doi:10.1016/S0040-6090(03)00389-4

${ }^{46}$ H. Zhou, Y. Lu, W. Chen, Z. Wu, H. Zou, L. Krundel, G. Li, Stimulating the comfort of textile electrodes in wearable neuromuscular electrical stimulation, Sensors (Basel), 15 (2015) 17241-57, doi:10.3390/s 150717241

${ }^{47}$ T. Polak, F. Markulin, A. C. Ehlis, J. B. M. Langer, T. M. Ringel, A. J. Fallgatter, Far field potentials from brain stem after transcutaneous vagus nerve stimulation: optimization of stimulation and recording parameters, J. Neural. Transm., 116 (2009) 10, 1237-42, doi:10.1007/s00702-009-0282-1

${ }^{48}$ C. Alon, G. Kantor, H. S. Ho, Effects of electrode size on basic excitatory responses and on selected stimulus parameters, J. Orthop. Sports Phys. Ther., 20 (1994) 29-35

${ }^{49}$ N. Sha, L. P. J. Kenney, B. W. Heller, A. T. Barker, D. Howard, M. Moatamedi, A finite element model to identify electrode influence on current distribution in the skin, Artif. Org., 32 (2008) 8, 639-43

${ }^{50}$ J. E. B. Randles, Kinetics of rapid electrode reactions, Discuss Faraday Soc., 1 (1947) 11-19, doi:10.1039/DF9470100011

${ }^{51}$ M. Reichmanis, A. A. Marino, R. O. Becker, Electrical correlates of acupuncture points, IEEE Trans. Biomed. Eng., BME-22 (1975) 533-535

${ }^{52}$ X. Gao, P. Rong, H. Ben, K. Liu, B. Zhu, S. P. Zhang, Morphological and electrophysiological characterization of auricular branch of vagus nerve: Projections to the NTS in mediating cardiovascular inhibition evoked by the acupuncture-like stimulation, Abstr. Soc. Neurosci., 694 (2010) 22/HHH45 